\title{
Bridges to Studying: Educational Migration in the Scope of Political Transformation in Post Covid-19 Pandemic in Europe
}

\author{
G.O. Abrokwa ${ }^{1}$, E. Donkor ${ }^{2}$ \\ ${ }^{1}$ RUDN University, Moscow, Russian Federation \\ ${ }^{2}$ Charles University, Prague, Czech Republic
}

\begin{abstract}
Recently, Europe is witnessing a transformation in the political system, concerning right-wing populist movements, around the claim that a massive influx of migrants within its territorial borders undermines the sovereignty of the nation-state. This transformation has led to issues of economic inequalities, loss of cultural identity, and influence in voting patterns. Considering the unfolding situations, we ask: What is the effect of educational migration on economic growth and social development before, during, and after the Covid-19 pandemic? How will the current political transformation processes affect educational migrants in the post-Covid-19 pandemic in Europe? Using the systematic review methodology, the authors sort to perform a comprehensive literature search; complete a critical appraisal of the individual studies gathered; and combine the valid studies using appropriate statistical techniques. The research affirmed a case that Education could not ignore politics. We perceive it will shape populist motives on educational migrants in post-pandemic Europe. The author's expectation of future research pays attention to the political transformation process and how anti-immigration discourse will exercise control over educational institutions.
\end{abstract}

Keywords: migration, educational migrants, political transformation, Covid-19, globalisation, populist parties

For citation: Abrokwa, G.O., \& Donkor, E. (2021). Bridges to studying: Educational migration in the scope of political transformation in post Covid-19 pandemic in Europe. RUDN Journal of Political Science, 23(1), 141-158. DOI: 10.22363/2313-1438-2021-23-1-141-158

(C) Abrokwa G.O., Donkor E., 2021

This work is licensed under a Creative Commons Attribution 4.0 International License https://creativecommons.org/licenses/by/4.0/ 


\title{
Мосты к обучению: образовательная миграция в контексте политической трансформации в период после пандемии Covid-19 в Европе
}

\author{
Г.О. Аброква ${ }^{1}$, Э. Донкор ${ }^{2}$ \\ ${ }^{1}$ Российский университет дружбы народов, Москва, Российская Федерация \\ ${ }^{2}$ Карлов Университет, Прага, Чехия
}

\begin{abstract}
Аннотация. В последнее время в Европе происходит трансформация политической системы, связанная с правыми популистскими движениями, дискурс которых сосредоточен на идее, что массовый приток мигрантов в европейский ареал подрывает суверенитет национального государства. Эта трансформация привела к проблемам экономического неравенства, утрате культурной идентичности и изменению электоральных моделей. В статье ставятся следующие исследовательские вопросы: каково влияние образовательной миграции на экономический рост и социальное развитие до, во время и после пандемии Covid-19? Как актуальные политические процессы повлияют на поведение образовательных мигрантов в период после пандемии Covid-19 в Европе? Проводится систематический обзор литературы на основе критической оценки, его выводы сопоставляются с валидными исследованиями с использованием статистических методов. Исследование подтвердило исследовательскую гипотезу, что образование не может развиваться в отрыве от актуальных политических процессов.
\end{abstract}

Ключевые слова: миграция, образовательные мигранты, политическая трансформация, Covid-19, глобализация, популистские партии

Для цитирования: Abrokwa G.O., Donkor E. Bridges to studying: Educational migration in the scope of political transformation in post Covid-19 pandemic in Europe // Вестник Российского университета дружбы народов. Серия: Политология. 2021. Т. 23. № 1. С. 141-158. DOI: $10.22363 / 2313-1438-2021-23-1-141-158$

\section{Introduction}

Migration, processes of political transformations and the novel coronavirus pandemic are seen to be double-edged swords that affect all sectors of the economy, geographical classifications, and some fundamentals of human existence. The transformation in the political process has been charged by anti-immigration sociopolitical mobilisation equating it to the perception of native culture and norms being hampered in the present and future years. Amidst all the numerous publications on migration, political transformation and the current pandemic, an unequal weight has been given to some basics of these global drivers in a categorical context. It is with this intuition that the authors seek to address objectively, some bridges to studying, taking into consideration a contextualised theme under Youth and Politics in Europe. The general objective of this reviewed article is on Educational Migration in the Scope of Political Transformation in Post Covid-19 Pandemic in Europe. Also, the article seek to review how the processes of political transformation in Europe affect the trend and factors of migration by education as well as socioeconomic growth? To achieve this, reviewing relevant pieces of literature, 
understanding the breadth and depth of the current body of work, and identifying gaps to inform further research was considered. This methodology was used because it is a comprehensive and thoroughly searched across different data-sources and grey areas that can be repeatedly explored and reproduced by other researchers. Inferring from this, literature inclusion criterion was based on systematic literature review principles which include coverage, focus, integration, validity, reliability, and repeatable or how the method is applicable universally. Significantly, the authors gave attention to abstract and findings of literature during the screening inclusion stage, and they short-listed the literature to ninety-seven publications based on the thematic questions the authors seek to address and the reliability concerning the replication of method. Four publications were excluded because it was not written in English. Concerning the questions above as well as keywords used at the literature and screening inclusion stage, full-text of pieces of literature were identified from databases with publication date limit set between 1997 and 2020. The authors then extracted some quantitative data from Eurostat, OECD and UNESCO based on the key areas of the question that the authors wanted to explore. These extracted data were analysed and interpreted by the authors with the assumption that the reliability of the extracted data informed the research's output. The findings had a different view from the right-wing parties' assertions on migration and it stressed on how policies on migration could affect the trends of educational migrants as well as the factors of migration by education and the economy in Post Covid-19 Pandemic in Europe. In the first section of this article, the authors addressed categorical issues on educational migrants trend, comprehensive factors for migration by education using infographics, as well as educational migrants effect on economic growth (considering before, during and post-Covid-19 pandemic) and social development. The effect of globalisation on migration and processes of transformation was also looked at in the second section of this article from a broader perspective of migration and politics and recommendations were given where necessary to inform future policies and scholarly works.

\section{Educational migrants' contributions to economic growth and social development}

Migration and migrants are defined technically in context, concepts and categories informed by geographic, political, legal, methodological, duration and other factors. In ascertaining the measurement of migration, four main categorisations were considered, including place of residence, place of birth, citizenship, and duration of stay ${ }^{1}$. Immigrants in the classical immigration countries (Australia, Canada, New Zealand, and the USA), were mainly based on the criterion of citizenship. In contrast, immigration data for European countries is based

\footnotetext{
1 International Organisation for Migration (2020). World Migration Report. Retrieved from https://publications.iom.int/system/files/pdf/wmr_2020.pdf
} 
primarily on the criterion of the place of residence and place of birth [Haas et al. 2014]. Pieces of literature were considered based on the definition for the first and second generation of educational migrants [Wirén 2013] as the unit of analysis.

The growth in educational migrants' numbers is part of a broader 'transnationalization of education' achieved through a range of factors including globalisation, advancement in technology, pedagogical upgrade, among others. Amidst conducted reviews is 'Evidence on education as a driver for migration' journal ${ }^{2}$ with particular attention to Tertiary education and International migration where Browne stressed on some factors that influence educational migration. It is in this light that the paper seeks to update the comprehensiveness of the stated factors in the journal with a pictorial representation (Fig. 1).

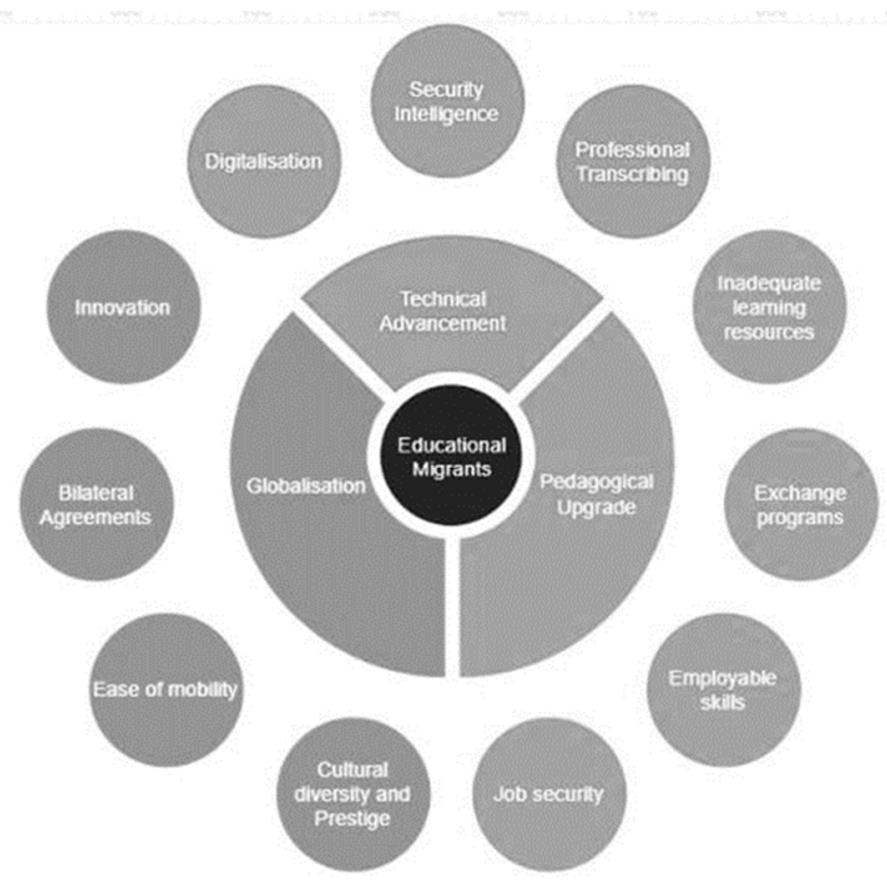

Fig. 1

The trend of migration by education in some EU member states

Source: Authors' own construct (an update of Browne, E. Evidence on Education as a Driver for Migration. K4D Helpdesk Report. Brighton, UK: Institute of Development Studies).

URL: https://assets.publishing.service.gov.uk/media/598086a0ed915d022b00003c/K4D_HDR_Migr ation_and_Education.pdf. (accessed: 09.11.2020)

Substantially, recent years have recorded an increase in the volume of educational migrants worldwide. These numbers have been rising, almost quartet faster than total international migration confirming the assertion that lower

${ }^{2}$ Browne, Evie (2017). Evidence on Education as a Driver for Migration. K4D Helpdesk Report. Brighton, UK: Institute of Development Studies. Retrieved from https://assets.publishing.service.gov.uk/media/598086a0ed915d022b00003c/K4D_HDR_Migration_and_Education.pdf 
education means fewer options for legal migration". Figure 2, shows the 'trend of this volume' ${ }^{4}$ in some selected countries.

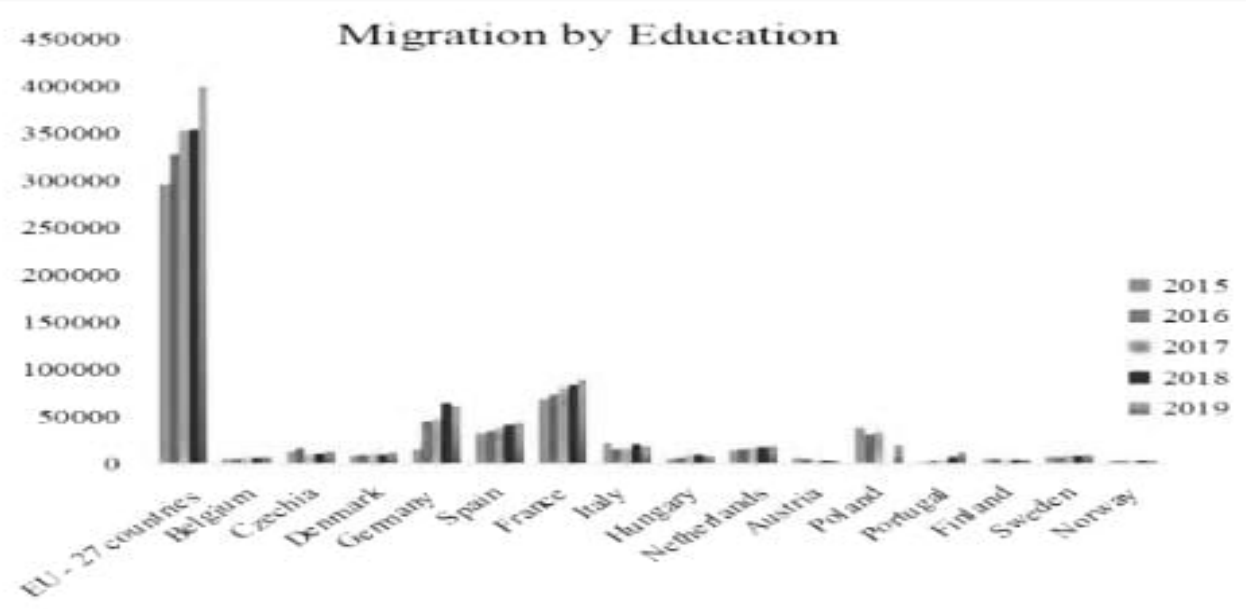

Fig. 2

Migration by Education

Source: Authors' own construct. OECD/Eurostat (2020). URL: https://read.oecd ilibrary.org/ education/education-at-a-glance-2020_974729f4-en\#page4 (accessed: 15.11.2020).

From Figure 2, Spain, France and Portugal had a significant and exponential increase of educational migrants from 2015-2019 which is consistent with the total inflow of educational migrants into EU-27 countries. Germany and Italy recorded a decline of 3,933 and 1,775 respectively from 2018 to 2019 whiles Norway recorded slightly steady growth from 2017 to 2019. The European Union is a critical geographical area with some of the countries seen as destinations for significant migration by education. In 2018 educational migrant recorded was 1.7 million from 23 OECD countries that are also members of the EU (EU-23) ${ }^{5}$. To be able to understand the weight of educational migrants, the total number of annual inflows were also considered for some selected countries.

In Figure 3 above, Belgium, Denmark, Hungary and Austria ${ }^{6}$ was part of countries studied. Interestingly, these countries had $0.06 \%, 2.46 \%,-14.34 \%$ and

\footnotetext{
${ }^{3}$ International Organisation for Migration (2008). World Migration. IOM, Geneva. Retrieved from https://publications.iom.int/system/files/pdf/wmr 2020.pdf

${ }^{4}$ See: Statistics | Eurostat (2020). Retrieved November 15, 2020, from https://ec.europa.eu/eurostat/ databrowser/view/migr_resfirst/default/table?lang=en. Figure 1 was sourced from the link attached and the graph was constructed by the author. These trajectories clearly show how countries differ in volume and the percentage at educational migrants increased. This to some extent suggests that countries may have differential approaches and complementing policies as far as educational migrants are concerned. ${ }^{5}$ European Commission (EC). (2010). Europe 2020: A strategy for smart, sustainable and inclusive growth. Working paper. Retrieved November 15, 2020, from https://www.eea.europa.eu/policydocuments/com-2010-2020-europe-2020

${ }^{6}$ See: Retrieved November 15, 2020, from https://read.oecd-ilibrary.org/education/education-at-aglance-2020_974729f4-en\#page4
} 
$1.30 \%$ respectively as a percentage change of migration by education from 2018 to 2019 , leaving us with the question of how significant is the influence of educational migrant's culture on the culture(s) of the countries mentioned above or what brought about these changes? These questions were answered by the authors using the simulation of an enclave-assimilation theory and policies on how educational migrants gradually adapt to their new environment.

\section{Share of migration by education and Total number of immigrants}

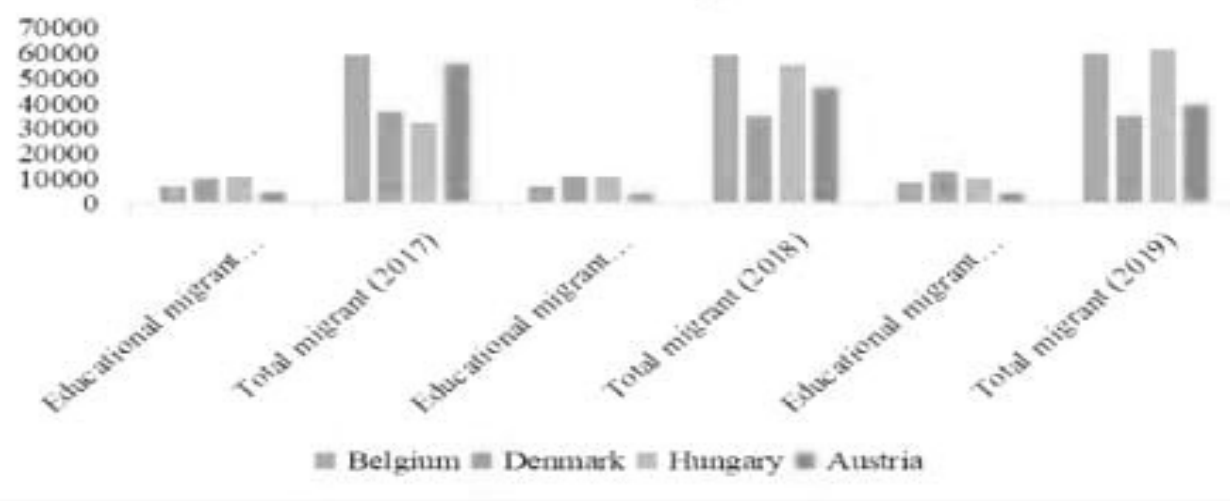

Fig. 3

Share of Migration by Education and Total Number of Immigrants Source: Authors' own construct. OECD/Eurostat (2020). URL: https://read.oecd ilibrary.org/ education/education-at-a-glance-2020_974729f4-en\#page4 (accessed: 15.11.2020).

In order to understand how the enclave-assimilation theory was applied, the authors looked at the spread of educational migrants by regions of origin [OECD $2020]^{7}$ since the authors assumed that the degree of enclave and assimilation perhaps could be affected by the heterogeneous characteristics of areas. Follow the link in the footnote to better understand a different perspective the authors looked at the Distribution of international and foreign students by region of region $\operatorname{graph}^{8}$ (page 232) from OECD's education at a glance report (2020).

These countries recorded $12 \%, 31 \%, 9 \%$ and $24 \%$ respectively as a share of educational migrants from the volume or the total number of immigrants recorded in 2019 (by Author's construct from migr_resfirst- Eurostat's online data).

According to European Migration Network (2019), the highest number of educational migrants coming to the EU in 2017 was from China - consisting almost a quarter of all first study permits (118 830 permits) - followed by the United States (33 000 permits) and India (32 317 permits). The top countries of origin for international students in the EU include Ukraine (16 248 permits), Morocco (13 472 permits), South Korea (11 358 permits), Brazil (10 414 permits) and Turkey (9 941 permits).

${ }^{7}$ See: Retrieved November 15, 2020, from https://read.oecd-ilibrary.org/education/education-at-aglance-2020_69096873-en\#page232

${ }^{8}$ See: Retrieved November 15, 2020, from https://asset.keepeek-cache.com/medias/domain21/_pdf/ media5256/801171-rr3m0fe9h3/large/231.jpg 
From authors' analytical glance, the distribution shows how educational migrants are assimilated into some destination countries in Europe (such as Czechia, Germany, Italy, France, the Netherlands and Latvia). For instance, there are diverse cultures in all the regions identified but particular attention were given to educational migrants coming from Asia, Europe and Africa. This is evident on how international students from these three major regions easily adapt to new environment because of their experience to cultural heterogeneity in their home countries. This study looked at the theory of assimilation concerning immigration in general, and it was narrowed to the context of Europe and categorically to educational migrants using 'Rethinking Assimilation Theory for a New Era of Immigration' journal by [Alba, Nee 1997a $]^{9}$ as a guide.

Some of the hypothesis the authors considered from [Alba et al. 1997b] work include (1) lower duration of educational migrant's socio-cultural and political enclave, (2) slower pace to assimilate educational migrants into host countries, and (3) second generational migrants and natives with a migration background will have the fastest transition and less/no available assimilation [consistent with the findings of Alba and Nee 1997] in the context of the proposed theory ${ }^{10}$. Based on the student Directive 2004/114/EC, diversified approaches have evolved to assimilate and aid in the selection of educational migrants which in turn led to different modules on how higher education systems recruit and integrate skilled foreign students into the local and national economy. Compensation strategies and enhanced revenue coming from abroad were some of the economic benefits associated with international students. Again, regional or national schemes were centred on attracting the 'brightest and the best' [MacGregor 2013; Rostovskaya et al. 2020]. Parallel to this, educational migrants come from a spread of geographical locations or origins and to achieve country-specific policies on education, English language is being used as a common language for tuition.

Conversely, Hungary and Latvia had no national policy on educational migrants. With Hungary, only an action plan has been formulated, and this is tailored to strengthening the education of ethnic Hungarians standards of living outside the territory of Hungary. The absence of a national policy on educational migrants to an extent explains the negative values of its percentage change from 2018 to 2019.

\footnotetext{
${ }^{9}$ See: Rethinking Assimilation Theory for a New Era of Immigration on JSTOR. Retrieved November 15,2020 , from https://www.jstor.org/stable/2547416?seq=1

${ }^{10}$ Globalisation to an extent has suggested a global identity in theory (see [Arnett, 2002]) so if the third assumption holds, then there's the likelihood for some degree of convergence from the perspective of solidarity. As stated, this calls for further studies.
} 


\section{Educational migrants and economic growth}

\section{Educational migrants' effect on economic growth before the Covid-19 pandemic}

Economic growth and gains emanating from migration by education have been analysed by some scholars using the balance of payment analogy ${ }^{11}$. According to [Bergerhoff et al. 2013] the proportion of educational migrant's inflow is likely to remain in the host country, and when this happens, it changes the trajectories of the labour force as well as the human capital in a given country and consequently leads to interesting growth effects.

On the one hand, migration by education from host countries point of view again may be an essential source of income and have a disproportionate impact on their economic and innovation systems. For instance, educational migrants contribute to the local economy through their living expenses (in the longer run) as well as innovation through practical and strategic integration into domestic labour markets. From countries of the origin point of view, on the other hand, educational migrants can contribute to knowledge (both tacit and experiential) absorption, technology progress and capacity building in their respective origins. This only happens when they return home after their studies or hold up a strong rapport with nationals at home, integrated into their areas of expertise and act as a magnet for diasporic investment [Marginson 2006].

According to [Chellaraj et al. 2008] educational migrants significantly contributes positively to government's budgets through highly paid taxes since there is a robust linear relationship between educational attainment and income and are apt to receive fewer government benefits than less-educated residents.

On the contrary, there is also an empirical finding of a negative net brain effect in transitional countries in a sense where many educated emigrants from thirdcountries or transitional countries end up in employment sectors classified as unskilled in the developed economies [Chiswick and Miller 2009]. The trickledown effect is that the origin country's human capital stock decreases with a diminishing incentive for future investment as far as migration by education is concerned.

\section{Migration by education effect on economic growth during Covid-19 pandemic}

More than 3.9 million international or foreign students studying in OECD countries were potentially affected due to the decree made by governments to (temporarily) close-down higher education institutions as a measure for controlling

\footnotetext{
${ }^{11}$ Bashir, S. (2007). The trends in international trade in higher education: Implications and options for developing countries. Washington, DC: World Bank. World Bank Education Working Paper Series no. 6. Retrieved November 17, 2020, from http://documents.worldbank.org/curated/en/ 828431468762899837/Trends-in-international-trade-in-higher-education-implications-and-optionsfor-developing-countries
} 
the spread of the COVID-19 pandemic $^{12}$. The crisis has impacted the ability of educational migrants who self-finance themselves during their studies since many are often dependent on student jobs. The global effect of this pandemic on the ability of a student's family in the country of origin to support their wards may also have experienced a negative impact. Therefore, this to some extent increases the financial burden of governments (from both origin and destination countries) in ensuring the wellbeing of students to the degree of the country's capacity ${ }^{13}$.

Conversely, France has established an annual legal working duration to increase full-time equivalent from 60 to $80 \%$ for foreign students legally and currently living in France as of $16^{\text {th }}$ March 2020 until the re-opening face-to-face studies.

\section{Migration by education effect on economic growth at post-Covid-19 pandemic}

To ensure the continuity of education despite the lock-down, higher education institutions have sought to use technology and offer virtual/online classes and learning experiences as a substitute for in-class time. Beyond the transactional learning experience, students are also losing out on other benefits of international mobility such as international exposure, access to a foreign job market, and networking ${ }^{14}$. With an emphasis on the widely accepted digitalised way of learning, the authors assumed that most third-countries or transitioning countries would strengthen their policies to make domestic education more attractive, advanced, resourced, and effective. These can convert some potentials to outputs in full capacity, which tend to enhance economies of scale [Ionescu, Polgreen 2009]. When these happen, human migration by education will reduce holding some factors constant whiles migration of digitalised knowledge increases. With a second scenario, the post-Covid-19 will call for more attractive (on a precondition that a vaccine is found) policies and higher economic incentives by the developed economies to pull innovative minded and skilled educational migrants at all levels from the developing countries. This incentive, to some extent, will intensify 'the competitive war for human capital' in the long run. Based on this, the authors assumed that the repercussion of these anticipated pull-policies might lead to a more extended stay of educational migrants in host countries. This intervention would tend to reduce the number of returnees, and in a way, promote the likelihood of unequal compensations through remittances. There will be a deficit in the labour market since some of the revision of countries immigration policies was to attract

\footnotetext{
12 UNESCO (2020). COVID-19 Educational Disruption and Response. UNESCO website. Retrieved October 29, 2020, from https://en.unesco.org/covid19/educationresponse

${ }^{13} \mathrm{EMN} / \mathrm{OECD}$ (2020). Impact of COVID-19 on international students in the EU and the OECD Member States - EMN-OECD Inform. Brussels: European Migration Network. Retrieved November 17, 2020, from https://ec.europa.eu/home-affairs/sites/homeaffairs/files/00_eu_inform2_students_final_en.pdf

${ }^{14}$ OECD (2020). "What is the profile of internationally mobile students?" In Education at a Glance 2020: OECD Indicators. OECD Publishing, Paris. Retrieved November 17, 2020, from https://doi.org/10.1787/974729f4-en
} 
skilled migrants to contribute to innovation, production and complement the working class of the population pyramid ${ }^{15}$. Again, a decrease in the share of educational migrants may have austere repercussions on the funding model of some advanced level of education institutions. The reason is that foreign students often pay higher tuition fees than domestic ones as the case of Czechia, Austria, Sweden, the Netherlands, Hungary, France, and Norway ${ }^{16}$.

\section{Educational migrants and social development}

In simultaneity with the cognitive process of globalisation, the generic trend towards more freely circulating goods, services, and capital together with more open labour markets, has encouraged increased trade in educational provision [Adnett 2010]. The authors, therefore, looked at how migration by education had affected social development before the Covid-19 pandemic since there was insufficient literature categorically on social development and migration by education during and post-covid-19 pandemic. As argued by [Mechtenberg, Strausz 2008], internationalisation could also boost the productivity of the economy due to the cultural experience that students obtain in foreign education. Parallel to this [Trooboff et al. 2007] posit that enterprises with an estimated international experience of less than $25 \%$ of sales abroad see international education as of less importance. Still, on the contrary, multinational companies even explicitly prefer international students based on diversity and multicultural value offering. This heterogeneity means that schooling abroad also increases cultural intelligence, experiences, and language competencies as evident in a survey of EU students studying in the United Kingdom [West 2000]. The subjective confidence and structural control parameters of international studies have both direct and indirect effect on social development. This effect assumed that the degree of one's attitude to pursue foreign studies, informs their planned behaviour, intentions, and studies outcome [Petzold, Peter 2015]. In this view, the next section of this paper considers both the geographical and the contextual impacts emanating from political transformation.

\section{Political transformation in Europe}

Across the globe, transitions in countries are made to improve the economic system where politics would be restricted. Notwithstanding, political reasons have been pivotal from the early stages and for subsequent development.

Recently, the migration trend across Europe has been characterised by a large number of people, mainly asylum seekers, refugees, job migrants and students. This

15 OECD (2019). Benchmarking Higher Education System Performance. Higher Education, Publishing, Paris. Retrieved November 17, 2020, from https://dx.doi.org/10.1787/be5514d7-en

${ }^{16}$ OECD (2020). "What is the profile of internationally mobile students?" In Education at a Glance 2020: OECD Indicators. OECD Publishing, Paris. Retrieved November 17, 2020, from https://doi.org/10.1787/974729f4-en 
situation has attracted opposing views and sentiments towards foreigners across the region in these recent years. Evidentially, immigration is seen as a fundamental reason for the rise of populist parties in these countries sparking a new dimension of political transition in these wealthy and advanced democracies [Halla et al. 2017; Kaufman 2017; Otto and Steinhardt 2014; Arzheimer 2009]. Many researchers have argued that aspect of immigration is the key influential factor for the rise of the transformation process across countries yet, other scholarly works have sided differently with this notion. They argue that although immigration maybe the main causal effect, other factors such as economic, cultural and other social dimensions linked with migration provides a strong basis on which these populist movements takes it roots for political agenda [Shehaj et al. 2019; Arzheimer 2009]. In this section, the authors examine several key indicators which have influenced the political transformation in the modern politics of Europe.

\section{Immigration and right-wing parties}

Across Europe, immigration is seen, as the significant influence of the rise of populist movements [Brubaker 2020; Shejaj et al. 2019; Dennison, Geddes 2019; Swain 2019; Grindheim 2019]. The recent transformation in the political process has been charged by an anti-immigration socio-political mobilisation equating it to the perception of native culture and norm being hampered in the present and future years. According to [Swain 2019], the projected influence against migrants brings negative sentiment has breed nationalism among host societies. Perhaps, party leaders try to avoid racial discrimination but rather push forward the phrase nativism. Well, notwithstanding how it is paraphrased, this use of native culture ideology has brought problems on integration in different countries. The [IOM 2020] ${ }^{17}$ report stated that the effort made for the acceptance and willingness of governments to cooperate among themselves and improve international migration has a considerable uncertainty about interconnectivity due to instability, demographic changes, climate altercations, political changes and decline in bilateral relations.

Presently, anti-immigration political mobilisation has taken the forefront, and populist parties and nationalistic agendas are rising rapidly throughout Europe. Most Populist Party leadership have used immigration as a tool to channel their message across board influencing voting patterns [Dennison, Geddes 2019], explained that most right-leaning populist parties in Europe possess similar characteristics in their political discourse. They criticise societal elites, particularly, on what they see as an integrated and anti-popular political elite; representation claims of 'the people' versus 'the elite'; protectionist and hostile to immigration; critical of minority politics; use rhetorical arguments which are at times extraordinarily value-laden and biased. They most often blame someone else for popular misery; nationally minded and willing to use nationalistic rhetoric and

17 World Migration Report 2020. (2019). ISSN: 1561-5502. Retrieved from https://publications.iom.int/books/world-migration-report-2020 
propaganda to win votes; and are against the European Union and their country's membership of the EU, C. Mudde argues ${ }^{18}$.

The populist backlash has emerged as an alarming trend shaping transformation process across the developed world in recent years. Examining the conditions under which immigration becomes especially important for populist parties is key to allow us to ascertain the transformation system. Several pieces of literature have identified and explained vividly, important factors that shape the connection between populism and migration. The authors review these works by analysing ways in which Populist Party's success hinges on immigrants and host citizen's countries in relation to economic reasons and cultural dimension.

\section{Economic factor}

The fear and anxiety of losing one's job coupled with the competitive nature in the labour market was an actual condition of the elevation of populism in several parts of Europe from 2013-2015. As argued by [Shehaj et al. 2019], the movements of people from a lower region to a higher-class society pushes psychological constraint on natives on the point of being pushed away from employment opportunities. Here, inexperience and low skilled citizens in host countries get enraged about the prospect of competition in job positions, especially in crunch economic times [Shehaj et al. 2019; Golder 2003]. Interestingly, the grievances take a different turn when immigrants are political mobilized. Researches done across some part of Europe confirmed that most far-right political leaders use the basis of economic benefits against immigration to induce mostly young voters, loweducated and either unemployed or into manual labourer [Shehaj et al. 2019; Arzheimer 2009; Givens 2007].

According to [Peri 2013], evidence from the analysis of capital expenditure and savings of host members proofed that there was no reduction in wages throughout high immigration periods, notwithstanding the growing sense of insecurity in foreign migrants. Again, low skilled host country workers in the labour-intensive market create high anxiety than those in high skilled labour [Shehaj et al. 2019], examined that, in a scenario that migrants have manual labour skills, they are easily attracted to jobs of manual nature and don't necessarily care about wages in the short-run, which makes it more competitive for native workers in same sectors. This condition directly influences right-wing parties' exploitation tactics of using economic grievances to lure native workers and amass political support.

\section{Cultural dimension}

According to [Turner, Brown, Tajfel 1979], the theory of social identity best explains the influence of cultural dimension with populist parties. The theoretical perspective claimed that a group of people with a particular way of life, defined identity

\footnotetext{
${ }^{18}$ Mudde, C. (2019). The Far Right May not Have Cleaned up, but its Influence Now Dominates Europe. The Guardian, 28.
} 
and traits finds it more comfortable to relate with people of similar background yet tends to differ from other sects of people with distinct identities and primarily perceive themselves as superior [Shehaj et al. 2019; Turner, Brown, Tajfel 1979].

In recent times, the influx of migrants has stipulated critical arguments of the disintegration of cultural identity and values among host societies. As indicated by [Shehaj et al. 2019], large movements' within-host territories are seen as a threat to norms that have been held for years. This has brought enormous consequences in the migration dilemma and the political transformation system across regions. More often Interest groups have this course to channel personal socio-political agenda. According to [Shehaj et al. 2019], the mere fact of fear and anger reproduces counter-reactions where populist groups chance upon to solicit political leadership positions. Here, right-wing parties use the idea of differences in identities to move nationalistic agenda to take native population votes in view of helping them to maintain their traditions. The results of this have poked issues of racial discrimination against immigrants in different countries. Again, the right-wing populist transition is further strengthened when they bridge the accord between migrants and natives, with strict adherence to nativism which promotes electoral support in communities and regional level.

Another aspect of the cultural dimension which has led to right-wing support and pushing the transformation processes in different countries is the religious beliefs of migrants [Bisin et al. 2011; Adida et al. 2010]. [Shehaj et al. 2019], stated that from 2005-2015, most immigrants who came from war and ethnic conflict communities into Europe were Muslims. They were mostly refugees from the Middle East and have strong religious identities different from the practice in Europe. Evidence shows that these group of people face labour market problems, economic inequalities, and social maltreatments due to their Islamic identities. The findings from the research showed that right-wing parties within the period capitalized on this as a political discourse to amass support from the native populace who perceive it as a threat to their norms and religious values. The point relates to cultural disintegration using religious practices which are radical and oppressive.

\section{Will populist movement in Europe influence educational immigration?}

To put it in simple terms, scholarly work of [Grindheim 2019] highlights the idea that populist movement in Europe doesn't strictly align to immigrant numbers but the rhetoric of immigration which exploits pre-existing social and economic inequalities and further creates fear and anger. There is no means we can denounce the dynamics of immigration in this rising populist parties. Yet, it is inconclusive to make it categorically a static medium which manifests this political ideology as there are other important connected factors. In this section, the authors review an important emerging force that is perceived to shape populist motives on educational migrants in post-pandemic Europe. Although, this theme has been touched-on in several scholarly works, its link to populism and how it can influence educational 
migration in subsequent years has been underestimated. It is therefore imperative to have a critical look, as a basis for further policy action.

\section{Globalisation}

In some respects, globalisation is synonymous to internationalisation. He described globalisation as growing interconnectedness and interdependence of people and institutions throughout the world. It shows the influence of a worldbased agenda over the local community. More comprehensive acquisition of knowledge and skills spread from education and as well as the dynamism of culture norms at different facets of society and its consequences of broadly available employment opportunities constitute the largest share of the globalisation process.

\section{Global interdependency versus populist movement}

The populist movements across Europe have stated their dissatisfaction against globalization in numerous channels categorically. Their arguments to globalisation have always been clear as a means of the unacceptability of social inequality, authoritarian regime, and breakdown of native culture. Right-wing parties in Europe have debated against the legal bindings of supranational entities and their ability to regulate systems to favour a global agenda. They are critical in preferences of jobs which must be competed for among people, prospects for goods and services which must be shared and even resource distribution paths. Among populist activist in other countries, there is a notion that the regional body (European Union) put many efforts in supporting foreign interests in trade, security, education at the expanse of local communities [Rizvi 2019].

Interestingly, most right-wing populist seems to side with some aspects of globalisation. Yet their dis-contention arises from the basis of the massive inflow of immigrants across its borders which turn to fuel cultural disintegration and economic inequality. As indicated by [Rizvi 2019], there is a sense of major threat to their livelihood conditions such as job, political leadership, culture integration etc. When these migrants are resettled within their premises. This new breed of the population tends to diversify their ways of traditions and religious beliefs in the long run.

Over the years, the populist parties have used this medium to mobilise political power, without formalized political approach but rather inconsistent ideas characterised by fear, emotions and panic stories to make enemies and have their political will achieved [Rizvi 2019]. Modern populist groups have argued that globalisation has lost its focus as it hasn't only allowed a free flow of capital but also people without proper assessment through borders, which has intensified negative sentiments against refugees, migrants' workers etc. There is an assumption they state that livelihood conditions among member states will be reinstated when border controls are tightened or blocked eventually. The instance of security threats has been used against minorities from certain third countries who are tagged with 
different religious and ethnic beliefs. They bodily refuse the principles and ideologies of diversity and multiculturalism that globalisation has allegedly promoted [Rizvi 2019].

Their proposed system of globalisation as described by [Smith 2010], explains that nations can be able to compete and align better when they are socially disintegrated with values, cultures, traditions which gives a vivid understanding of their personality. The point here is a clear case of Nationalism which makes a country stuck to its core political, cultural, and economic interest at the expense of others. Nationalism has been the pivot of these populist parties against globalisation in recent times, and their basis for promoting this ideology is to give them territorial powers [Smith 2010].

\section{Educational challenges}

Globalisation has been beneficial to societies across borders as it has open new ways of life and better opportunities. Contrary to that, the interconnectedness has sprung different form of negative sentiments, separatist agendas, and socio-political nationalism. Education cannot ignore politics. Assessing the political dimension that globalisation has been channelled, we seek to ask this question; Since educational institutions across Europe are culturally diverse and transnationally connected in recent years, what challenges do educational migrants face in postpandemic Europe?

Significantly, cultural diversity poses a much difficult problem for educational institutions and international students. With the 'new normal', the term that is being echoed across the globe, migrants face an issue of being accommodated into practices of new regulations and norms. The assimilation and integration process of these minorities into a politically dominated populist culture poses a risk to their education. Here, the populist group will pose power of imposing various norms and practices, different from an open society views based on curtailing future pandemic risk. The authors firmly agree with the assertion made by [Rizvi 2019], about a politically motivated group who won't allow their privileges to be infringed upon in situation of having a dominant majority power based on the similar pre-existing issue.

Furthermore, institutions will put measures to make it possible for their students to be embedded in complex transnational systems of learning and can access sources of educational information across borders of the nation. Diverse educational modules and practices are now constantly being used in different levels of education which has open the possibilities of new hybridized practices through the greater potential for intercultural communication and education [Rizvi 2019]. Contrary, to the above assertion, educational migrants would have to understand that a climate of the unknown (political-induced) has emerged in many parts of the world, and students can be asked to stay put in their home countries and study; change the mode of study from full-time face-to-face learning to the online mode of study; or even be sent home to finish up their study when the means cannot be contained. 
The authors believe that this anxiety and fears in studies cannot be ignored as it will have a psychological toil on many international students in post-pandemic Europe and that member states will not be bothered by the broader opinion and debates about global interconnectivity with respect to education.

Evidentially, politics is driving communities across the continent, which has made right-wing parties to further expand their ideological propositions to be more secured. Perhaps, educational institutions have none other option but acquaint their students not only to be proactive towards social change around them but cope with the rate of the political shift operating in the region. Here, educational migrants will face a broader issue of practising different forms of ethics that might be complex, specific, contingent, uncertain, and diverse from their origin. Issues will be a transnational and involved political dimension that must be tackled differently from previously existing norms. Students must understand and comply with the severity and consequences of the profound changes that they and their communities will be experiencing. Moreover, the knowledge acquisition that they will seek might no longer assume universal norms and rules, not because of the institutional arrangement but due to political inclination. The relevance of education has the means of empowering specific action in global politics, and this includes both intratransformation and the inter-transformation with others [Rizvi 2019].

\section{Findings and conclusion}

The modern transformation in the political process in Europe has been charged by an anti-immigration socio-political mobilization equating it to the perception of native culture and norm being hampered in the present and future years. However, this does not fit the current measure and description of this phenomenon and how this can influence educational migration in subsequent years. The authors review these works by analyzing ways in which Populist Party's success hinges on immigrants and host citizen's countries in relation to economic reasons, cultural dimension, bipartisan politics, cultural globalization, and inequality. The findings show that migrants from different socio-cultural and religious background give right-wing parties the privilege to use immigration issue to their advantage in public discourse. This new order will suggest that educational migrants should then have to understand that a climate of the unknown has emerged in many parts of the world. Based on this, students can be asked to stay put in their home countries and study, changes in the mode of study from full-time face-to-face learning to the online mode of study will be the order of the day. In extreme cases, students might go home to finish up their study, if and only if, Covid-19 pandemic penetrate through hopes of getting a vaccine coupled with issues arising from the complexities of transnationalism. On the contrary, the vaccine to cure the pandemic will be found, and mass educational migration perhaps might happen which in the long run will worsen inequality between host and sending countries. If this happens, educational institutions need to acquaint their students not only to be proactive towards social change around them but cope with the rate of the political shift operating in the 
region. The author's expectation of future research pays attention to the political transformation process and how anti-immigration discourse will exercise control over educational institutions.

Received / Поступила в редакцию: 06.11.2020

Accepted / Принята к публикации: 12.11.2020

\section{References / Библиографический список}

Adida, C. L., Laitin, D. D., \& Valfort, M. A. (2010). Identifying barriers to muslim integration in France. Proceedings of the National Academy of Sciences, 107(52), 22384-22390.

Adnett, N. (2010). The growth of international students and economic development: Friends or foes? Journal of Education Policy, 25(5), 625-637.

Alba, R., \& Nee, V. (1997a). Rethinking assimilation theory for a new era of immigration. The International Migration Review, 31(4), 826-874. DOI: 10.2307/2547416. Retrieved from https://www.jstor.org/stable/2547416.

Alba, R., Logan, J., \& Crowder, K. (1997b). White ethnic neighbourhoods and assimilation: The Greater New York Region, 1980-1990. Social Forces, 75, 883.

Arnett, J. (2002). The psychology of globalisation. American Psychologist, 57, 774-783.

Arzheimer, K. (2009). Contextual factors and the extreme vote in Western Europe, 1980-2002. American Journal of Political Science, 53(2), 259-275.

Bergerhoff, J., Borghans, L., Seegers, P., \& Van Veen, T. (2013). International Education and Economic Growth. Institut zur Zukunft der Arbeit/Institute for the Study of labour, Bonn, Germany.

Bisin, A., \& Verdier, T. (2011). The economics of cultural transmission and socialization. In Handbook of social economics North-Holland. 1, 339-416.

Brubaker, R. (2020). Populism and nationalism. Nations and Nationalism, 26(1), 44-66.

Chellaraj, G., Maskus, K., \& Mattoo, A. (2008). The contribution of international graduate students to US innovation. Review of International Economics, 16(3), 444-62.

Chiswick, B., \& Miller, P. (2009). Educational Mismatch: Are High-Skilled Immigrants Really Working at High-Skilled Jobs and the Price They Pay if They Aren't? Bonn: Institute for the Study of labour. IZA Discussion Paper, 4280.

Daun, H. (2001). Educational Restructuring in the Context of Globalization and National Policy. New York: Garland.

Daun, H. (2001). Educational Restructuring in the Context of Globalization and National Policy. New York: Garland.

Dennison, J., \& Geddes, A. (2019). A rising tide? The salience of immigration and the rise of anti-immigration political parties in Western Europe. The Political Quarterly, 90(1), 107-116.

Givens, T. E. (2007). Immigrant integration in Europe: Empirical research. Annu. Rev. Polit. Sci., 10, 67-83.

Golder, M. (2003). Explaining variation in the success of extreme right parties in Western Europe. Comparative Political Studies, 36(4), 432-466.

Grindheim, J. E. (2019). Why right-leaning populism has grown in the most advanced liberal democracies of Europe. The Political Quarterly, 90(4), 757-771.

Haas, D., Hein, S. C., \& Mark, J. M. (2014). The Age of Migration: International Population Movements in the Modern World. 5th ed. Hampshire, UK: Palgrave Macmillan.

Halla, M., Wagner, A. F., \& Zweimuller, J. (2017). Immigration and voting for the far right. Journal of the European Economic Association, 15(6), 1341-1385.

Ionescu, F., \& Polgreen, L. (2009). A theory of brain gains and public funding for higher education in the United States. American Economic Review, 99(2), 517-521.

Kaufman, E. (2017). Levels or changes? Ethnic context, immigration and the UK Independence Party vote. Electoral Studies, 48, 57-69.

MacGregor, K. (2013). EUROPE Report Overviews: International Students in Europe, 266. 
Marginson, S. (2006). Dynamics of national and global competition in higher education. Higher Education, 52, 1-39.

Mechtenberg, L., \& Strausz, R. (2008). The Bologna process: How students mobility affects multicultural skills and educational quality, International Tax and Public Finance, 15, 109-130.

Otto, A. H., \& Steinhardt, M. F. (2014). Immigration and election outcomes: Evidence from city districts in Hamburg. Regional Science and Urban Economics, 45, 67-79

Park, R. E. (1930). Assimilation, Social. In Encyclopedia of the Social Sciences. Ed. E. Seligman and A. Johnson. New York: Macmillan.

Peri, G. (2013). Immigration, native poverty, and the labor market. In D. Card. \& S. Raphael (Eds.), Immigration, Poverty, and Socioeconomic Inequality. The National Poverty Center Series on Poverty and Public Policy. New York: Russell Sage Foundation (pp. 29-59).

Petzold, K., \& Peter, T. (2015). The social norm to study abroad: Determinants and effects. Higher education, 69(6), 885-900.

Rizvi, F. (2019). Global interconnectivity and its ethical challenges in education. Asia Pacific Education Review, 20(2), 315-326.

Rostovskaya, T. K., Skorobogatova, V. I., Pismennaya, E. E., \& Bezverbny, V. A. (2020). Incoming and outgoing academic mobility in Russia and abroad: Main trends, administrative challenges. International Journal of Sociology and Social Policy. Vol. ahead-of-print No. ahead-of-print. DOI: 10.1108/IJSSP-03-2020-009188

Shehaj, A., Shin, A. J., \& Inglehart, R. (2019). Immigration and right-wing populism: An origin story. Party Politics, 1354068819849888.

Shibutani, T., \& Kwan, K. (1965). Ethnic Stratification. New York: Macmillan.

Smith, A. (2010). Nationalism: Theory, ideology, history. Cambridge: Polity Press.

Swain, A. (2019). A Paper Prepared for the Development Policy Analysis Division of the United Nations, Department of Economics and Social Affairs, June 2019. Retrieved from https://www.un.org/development/desa/dpad/wp-content/uploads/sites/45/publication/SDO_ BP_Swain.pdf

Trooboff, S., Berg, M. V., \& Rayman, J. (2007). Employer attitudes toward study abroad. Frontiers: The Interdisciplinary Journal of Study Abroad, 15(1), 17-34.

Turner, J. C., Brown, R. J., \& Tajfel, H. (1979). Social comparison and group interest in ingroup favoritism. European Journal of Social Psychology, 9(2), 187-204.

Turner, J. C., Brown, R. J., \& Tajfel, H. (1979). Social comparison and group interest in ingroup favouritism. European Journal of Social Psychology, 9(2), 187-204.

West, A. (2000). Reasons for Studying Abroad: A Survey of EU Students Studying in the UK, Education-line, Edinburgh.

Wirén, E. (2013). Migrants in Education - What Factors are Important? Publications Office of the European Union. DOI: 10.2788/78189

\section{About the authors:}

Abrokwa Godfred Ohemeng - PhD (Candidate) in Political Science, Department of Comparative Political Science, People's Friendship University Russia (e-mail: 1042205062@pfur.ru) (ORCID ID: 0000-0002-7344-5698).

Donkor Emmanuel - PhD (Candidate) in Migration and Urban Studies, Department of Social Geography and Regional Development, Charles University, Czech Republic (e-mail: donkore@natur.cuni.cz) (ORCID ID: 0000-0002-5000-7839).

\section{Сведения об авторах:}

Аброква Годфред Охеменг - аспирант кафедры сравнительной политологии Российского университета дружбы народов (e-mail: 1042205062@pfur.ru) (ORCID ID: 0000-0002-7344-5698).

Донкор Эммануэль - аспирант кафедры социальной географии и регионального развития Карлова университета (e-mail: donkore@natur.cuni.cz) (ORCID ID: 0000-0002-5000-7839). 